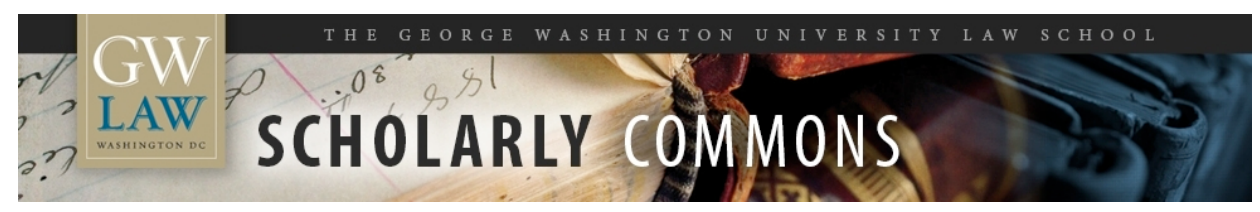

\title{
Privilege Objections to Grand Jury Subpoenas for Documents
}

Stephen A. Saltzburg

George Washington University Law School, ssaltz@law.gwu.edu

Follow this and additional works at: https://scholarship.law.gwu.edu/faculty_publications

Part of the Law Commons

\section{Recommended Citation}

Saltzburg, Stephen A., Privilege Objections to Grand Jury Subpoenas for Documents (2012). 27 Crim. Just. (2012) ; GWU Law School Public Law Research Paper No. 2012-155; GWU Legal Studies Research Paper No. 2012-155. Available at SSRN: http://ssrn.com/abstract=2669937

This Article is brought to you for free and open access by the Faculty Scholarship at Scholarly Commons. It has been accepted for inclusion in GW Law Faculty Publications \& Other Works by an authorized administrator of Scholarly Commons. For more information, please contact spagel@law.gwu.edu. 


\section{Privilege Objections to Grand Jury Subpoenas for Documents}

\section{BY STEPHEN A. SALTZBURG}

$\mathrm{O}$ ne of the well-established principles relating to grand juries is that they have the right to investigate any criminal activity that is or might be ongoing in their respective jurisdictions and to determine how much evidence to seek in the course of an investigation. They do not need reasonable suspicion or probable cause to call witnesses to testify nor to subpoena documents. As long as testimony or documents reasonably might be relevant to an investigation, the grand jury can seek to obtain evidence.

As the United States Court of Appeals for the First Circuit wrote in In re Grand Jury Subpoena (Mr. S. ), 662 F.3d 65, 69 (1st Cir. 2011), "[i]t is an ancient platitude that a grand jury has a right to every man's evidence." But that court also recognized that there are limits, and one is that a valid claim of privilege can trump a grand jury subpoena and cause a court to quash the subpoena. Two common privilege claims are attorney-client and self-incrimination, both of which were at issue in $M r . S$.

The Facts of Mr. S.

Mr. S. and attorney Doe (pseudonyms used by the court to protect grand jury secrecy) were client and lawyer. Mr. S. claimed that Doe is licensed to practice law and presents himself as having special expertise in real estate transactions and that Mr. S. sought Doe's assistance in connection with a particular real estate transaction that became the focus of a grand jury subpoena.

Doe received a federal grand jury subpoena seeking:

Any and all records relating to the purchase of real property by [Mr. S.] from [Mr. and Mrs. X] on November 20, 2007, that was

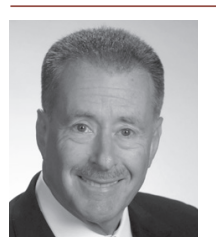

STEPHEN A. SALTZBURG is the Wallace and Beverley Woodbury University Professor at George Washington University School of Law in Washington, D. C. He is a past chair of the Criminal Justice Section and a regular columnist for Criminal Justice magazine. He is also author of the book, Trial Tactics, Second Edition (American Bar Association 2009), an updated and expanded compilation of his columns. facilitated by [Attorney Doe's Law Office and Title Company], including, but not limited to, real estate HUD statements, closing statement, sales contract(s) and record of payment, particularly the source and type of funds used (cash, personal check, bank checks, etc.) to purchase the property by [Mr. S.] and/or any other person. (Id. at 68 (alterations in original).)

Upon receipt of the subpoena, Doe contacted Mr. S. to ask if Mr. S. had an objection to the subpoena. Mr. S. gave verbal consent, and Doe complied with the subpoena and delivered the documents to the grand jury. Within days, though, Mr. S. had second thoughts and retained separate counsel, who notified the US attorney's office that the documents were privileged. The documents had been examined by a government paralegal, but the US attorney's office put them under seal while the privilege claim was litigated.

Mr. S. filed a motion to quash the subpoena and raised two privilege claims. His principal claim was that the subpoenaed documents were protected by the attorney-client privilege. Mr. S. argued that he sought Doe's legal services, as a licensed attorney with a real estate specialty, in connection with the real estate transaction identified in the subpoena, and that Doe represented him in that transaction, billed him for services rendered, and used his client trust account in the course of the representation. To make clear that he believed Doe was performing legal services, Mr. S. noted that Doe employed the term "Esquire" in the documents and correspondence that he signed.

Mr. S.'s backup claim was that the documents were protected by the Fifth Amendment privilege against self-incrimination because his act of producing the documents would have been testimonial and covered by the privilege had he been served with the subpoena and been in possession of the documents. He relied upon the Supreme Court's decision in Fisher v. United States, 425 U.S. 391 (1976), for the proposition that his attorney cannot be compelled to produce documents that Mr. S. could not have been compelled to produce.

A magistrate judge examined the documents in camera and rejected the privilege claims, finding that nothing in the documents reflected that Mr. S. sought or was provided legal advice. The judge also found that the documents "lack a confidential nature," and denied the motion to quash. ( $M r$. S., 662 F.3d at 68.) The court of appeals affirmed.

\section{Attorney-Client Privilege}

Mr. S.'s first argument was that the magistrate judge erred in examining the documents in camera. He relied on the Supreme Court's decision in United 
States v. Zolin, 491 U.S. 554 (1989), where the Court held that when a party claims the crime-fraud exception to the attorney-client privilege, the party must demonstrate some evidence to support the claim before a judge may examine the documents in camera. The First Circuit reasoned that it is not necessary to resort to the exception until the privilege itself has attached, and the privilege does not attach until the party claiming it makes a proper showing - which did not occur in this case. The court added that "the very purpose of conducting an in camera review is to determine which, if any, of a group of documents are privileged"; "[g]iven this prudential purpose, in camera reviews should be encouraged, not discouraged"; and "[w]hen, as in this case, the assertion of privilege is subject to legitimate dispute, the desirability of in camera review is heightened." (Mr. S., 662 F.3d at 70.)

Mr. S. also argued that the magistrate judge required him to prove entitlement to claim privilege by a preponderance of the evidence, whereas he should only have been required to make a prima facie showing of privilege. Despite the fact that disputed issues relating to admissibility are ordinarily determined by a preponderance standard under rules such as Federal Rule of Evidence 104(a), the court of appeals avoided prescribing the standard that a judge must use in deciding privilege claims. Instead, the court wrote:

It is clear beyond hope of contradiction that the party seeking to invoke the attorney-client privilege must carry the devoir of persuasion to show that it applies to a particular communication and has not been waived. Whatever quantum of proof is necessary to satisfy this obligation, a blanket assertion of privilege is generally insufficient. Determining whether documents are privileged demands a highly fact-specific analysis - one that most often requires the party seeking to validate a claim of privilege to do so document by document.

(Id. at 71 (citations omitted).)

In the end, the court agreed with the magistrate judge that Mr. S.'s blanket claim of privilege failed to demonstrate entitlement to attorney-client privilege. The court reasoned that "Mr. S.'s assertion of privilege is especially weak because the documents listed in the subpoena-HUD statements, closing statement, sales contract(s) and records of payment indicating the source and type of funds used - would all have been revealed at the closing and are, therefore, not confidential in nature." (Id. at 71-72.) Thus, there was no expectation that these documents were confidential.

Moreover, the court expressed doubts that Doe actually provided legal advice. It wrote the following: "Not every piece of an attorney's work product falls within the attorney-client privilege. Where, for example, an attorney acts merely as a scrivener-facilitating the consummation of a real estate transaction, passing title, and disbursing funds - the documents generated by those actions are typically not privileged." (Id. at 72.) The court concluded that Mr. S. failed to show that Doe was more than a scrivener and disburser of funds in connection with the real estate transaction.

\section{Privilege against Self-Incrimination}

The Supreme Court's decision in Fisher recognized three concepts. First, people can incriminate themselves by responding to a subpoena. If, for example, a subpoena is issued to $\mathrm{X}$ to produce the knife $\mathrm{X}$ used to stab Y, production of the knife by X would be tantamount to stating "this is the knife I used to stab Y." In this example, X would be able to quash the subpoena. Second, not all acts of production are incriminating. In Fisher, the government sought documents prepared by accountants and provided to lawyers by their taxpayer-clients, and the taxpayers were unable to make a showing that, had they possessed the documents and turned them over, they would have done anything incriminating. Third, the Court held that if the taxpayers would have potentially incriminated themselves had they received subpoenas and turned over the documents, the attorney-client privilege could be invoked to prevent their attorneys from being compelled to produce the documents. To use the previous example, if $\mathrm{X}$ had turned over a knife to his attorney (ignore for now whether this is permissible) and the attorney had received a subpoena to "produce the knife $\mathrm{X}$ used to stab Y," X would be able to claim attorney-client privilege and quash the subpoena because the attorney could only respond to the subpoena based on what X said in confidence; production would, therefore, reveal a privileged communication.

With this background, the court of appeals reasoned as follows:

To begin, the record does not indicate that Mr. S. transferred any preexisting documents to Doe. Based on the assertions made in $\mathrm{Mr}$. S.'s motion papers, he approached Doe to complete a discrete real estate transaction. For aught that appears, Doe himself prepared the standard documents needed to consummate the transaction, handled the closing, disbursed the funds, and retained copies of the documents and payment records. (Mr. S., 662 F.3d at 73.)

Thus, it seems that Mr. S. failed to show that, if he personally had the documents and was subpoenaed, 
his production could have been incriminating, given that he had no apparent role in their preparation.

The court added that

[u]ltimately, though, determining whether the subpoenaed documents are preexisting or not is of no moment. Either way, there is no showing that they are protected by the attorney-client privilege because, for reasons already explained, Mr. S. failed to establish that any documents were tendered to Doe for the purpose of obtaining legal advice. (Id. at 73-74.)

In other words, the court interpreted Fisher as only applying when a client seeks legal advice from a lawyer concerning documents that the client transfers to the lawyer.

\section{Lessons}

1. Grand juries have broad subpoena power and can issue subpoenas to clients, lawyers, or both. The subpoenas need not be based on reasonable suspicion or probable cause.

2. A valid claim of privilege can trump a grand jury subpoena and result in its being quashed, but the burden is on the person claiming privilege to demonstrate entitlement. Although the First Circuit did not finally determine the burden that applies, it is likely to be a preponderance of the evidence in most courts.

3. Not all documents that clients give to lawyers or that lawyers prepare for clients are privileged. Generally speaking, preexisting documents (i.e., those that existed before the attorney-client relationship) are not privileged because they were not made as part of the attorney-client relationship. What clients tell their attorney about preexisting documents will be privileged, as long as the clients are seeking legal advice.

4. A lawyer who acts as a mere scrivener or a disburser of money may not be deemed to be providing legal advice, and the privilege may not attach to documents prepared by a scrivener or that simply reflect a disbursement.

5. A person may validly claim a privilege against self-incrimination when production of a document may be tantamount to providing incriminating information. As $M r$ r. S. recognized, "[s]uch a case may arise when an individual's compelled production of documents would amount to a tacit concession that the documents exist, are authentic, and are in his custody or control." (Id. at 73.) But, the burden is on a person claiming the privilege to show that there is reason to believe that production could be incriminating.

6. Finally, clients may object to their lawyers responding to subpoenas where production by the lawyer would violate the attorney-client privilege as Fisher recognized. But to successfully object, a client must show that if the documents were in the client's hands, production in response to a subpoena would violate the client's privilege against self-incrimination. 